\title{
Formula of Moulding Sand, Bentonite and Portland Cement toImprove The Quality of Al-Si Cast Alloy
}

\author{
Andoko $^{1, a^{*}}$, Poppy Puspitasari ${ }^{1}$, AvitaAyuPermanasari ${ }^{1}$ and DidinZakariaLubis ${ }^{1}$ \\ ${ }^{I}$ Department of Mechanical Engineering, Faculty of Engineering, Universitas Negeri Malang \\ andoko.ft@um.ac.id
}

\begin{abstract}
A binder is any material used to strengthen the bonding of moulding sand grains. The primary function of the binder is to hold the moulding sand and other materialstogether to produce high-quality casts. In this study, there were four binder compositions being tested, i.e. 5\% bentonite $+5 \%$ Portland cement, $4 \%$ bentonite $+6 \%$ Portland cement, $6 \%$ bentonite $+4 \%$ Portland cement, and $7 \%$ bentonite $+3 \%$ Portland cement. Each specimen was measured for its compressive strength, shear strength, tensile strength and permeability. The highest compressive strength was obtained fromthe specimen composed of $6 \%$ bentonite+ 4\% Portland cement. The highest shear strength was obtained from the moulding sand with $7 \%$ bentonite $+3 \%$ Portland cement. The highest tensile strength was obtained fromthe specimen contained 5\% bentonite $+5 \%$ Portland cement. The specimen composed of 5\% bentonite $+5 \%$ Portland cement had the lowest permeability of $131 \mathrm{ml} / \mathrm{min}$, while that of $6 \%$ bentonite $+4 \%$ Portland cement had the highest permeability of $176 \mathrm{ml} / \mathrm{min}$..

Copyright (C) 2017Journal of Mechanical Engineering Science and Technology

All rights reserved

Keywords: Bentonite, Portland cement, Strength of moulding sand.
\end{abstract}

\section{Introduction.}

Casting systems and processes cannot be separated from moulds. To date, sand mouldis the most popular among other types of moulds [1]. In manufacturing sand moulds, the sand is undergone a process of compaction. Moulding sand is formed from a mixture of sand, binder and other additional materials [2]. Moulding sand is the most frequently used component in metal casting process due to its low production cost, reusability, thermal resistance, ease of operation, and acceptable quality [2]. Sand moulded casting is carried out through several stages, such as placing a pattern in the sand to form a mould cavity [3].

Green sand casting is known for its low-cost production. However, due to its low-strength mould, cast defects are often found in the products of green sand casting in which clay is used as a binder. In order to avoid this shortcoming, dry sand can be used as a possible alternative, but it takes a long time for the casting to completely dry. Thus, as an attempt to produce a mould that can dry up in a short time, this following step can be taken, i.e. by utilising a type of binder which has no drawbacks such as the emergence of gas defects, poor fire resistance, costly production, and complex mould production process [1]. Several materials that can be used as special binders are water-glass, resin, cement, flour, and others. Binder, as a vital element in the composition of sand moulds, certainly affects the quality of casting products.

As a binding agent, bentonite is most commonly used alone[4]. In this study, the casting process involved the combination of bentonite and Portland cement as the moulding sand binder. This mixture was expected to generate a binder formula with a high level of binding that can minimise any potential defects in the casting products [4]. The standard composition of a binder is usually 7.5 $9.1 \%$ bentonite and $3.7-4.5 \%$ water [3]. Also, other ingredients such as charcoal powder, flour, petroleum coke, or graphite flour by $1 \%$ are sometimesadded to create a smooth casting surface and allow easy casting removal [1]. Portland cement [5] is a moulding sand binder that can solidify itself and is composed of $85-88 \%$ silica sand, 6-12\% cement, and $4-8 \%$ water [6,7].It can also be added witha hardenersuch as molasses or calcium chloride as much as $50-100 \%$ of the total amount of cement. 
Table 1. Compressive, shear, and tensile strength of sand moulds with different compositions

\begin{tabular}{ccccc}
\hline Type of Testing & $\mathbf{5 \%} \mathbf{B}+\mathbf{5 \%} \mathbf{P C}$ & $\mathbf{4 \%} \mathbf{B}+\mathbf{6 \%} \mathbf{P C}$ & $\mathbf{6 \%} \mathbf{B}+\mathbf{4 \%} \mathbf{P C}$ & $\mathbf{7 \%} \mathbf{B}+\mathbf{3 \%} \mathbf{P C}$ \\
\hline $\begin{array}{c}\text { Compressive } \\
\text { Strength }\end{array}$ & 7.20 & 7.03 & 8.13 & 7.93 \\
\hline Shear Strength & 2.60 & 2.70 & 2.63 & 2.86 \\
\hline Tensile Strength & 0.51 & 0.51 & 0.51 & 0.46 \\
\hline
\end{tabular}

\section{Material and method.}

Data were collected through sand identification, compression, tensile and sheartesting, and permeability testing. The sand was combined with different amount of bentonite and Portland cement, i.e. $5 \%$ bentonite (B) $+5 \%$ Portland cement(PC), $4 \%$ bentonite $(\mathrm{B})+6 \%$ Portland cement $(\mathrm{PC}), 6 \%$ Bentonite $(\mathrm{B})+4 \%$ Portland Cement $(\mathrm{PC})$, and $7 \%$ Bentonite $(\mathrm{B})+3 \%$ Portland cement (PC). The results of strength and permeability testing of each variation were averaged and compared.As a follow-up, a morphology testusing the Scanning Electron Microscope (SEM) was performedto identify the surface shape produced by the formula above.

\section{Results and discussion.}

Based on the test results, this section discusses the effect of variations in the binder composition of the moulding sand to improve the quality of casts. Several tests were carried out to assess the compressive, shear, and tensile strength, permeability and surface morphologyof sand mould composed of different amounts of bentonite (B) and Portland cement (PC) as the binder. The results of compression, shear, and tensile testingare presented in Table 1.

\section{A. Compression Testing on the Moulding Sand}

The compression testing on the specimen composed of 5\% bentonite and 5\% Portland cement showed that it had a compressive strength of $7.2(\mathrm{~N} / \mathrm{Cm} 2)$ or $72 \mathrm{KN} / \mathrm{m}$. The compressive strength of themouldcomposed of $4 \%$ bentonite and $6 \%$ Portland cement was $7.03(\mathrm{~N} / \mathrm{Cm} 2)$; this value inkN/m² in line with Tjitro and Hendri was $70.3 \mathrm{kN} / \mathrm{m} 2$. The specimen composed of $6 \%$ bentonite and $4 \%$ Portland cement had a compressive strength of $8.13(\mathrm{~N} / \mathrm{Cm} 2)$ or $81.3 \mathrm{kN} / \mathrm{m} 2$. The combination of $7 \%$ bentonite and 3\% Portland cement generated a mould with a compressive strength of 8.3 $(\mathrm{N} / \mathrm{Cm} 2)$ or $83 \mathrm{kN} / \mathrm{m} 2$. [8] stated that the ideal of compressive strength of green sand mouldis between $0-1.0 \mathrm{~kg} / \mathrm{cm} 2$. Therefore, the four specimenscan be considered of having an ideal compressive strength $(0>0.0073-0.0083<1 \mathrm{~kg} / \mathrm{cm} 2)[9]$.

\section{B. Shear Testing on the Moulding Sand}

To measure the maximum shear strength, each sand mould was subjected to shear loading until it was damaged or broken. If the shear strength of a mould is low, the molten metal will flowthrough the mouldwallandwash away the sand, causing sand erosion and inclusion [3].The standard shear strength is 1.5-7 Psi. Based on the shear testing result, the sand mould composed of 5\% bentonite and $5 \%$ Portland cement had a shear strength of $2.8(\mathrm{~N} / \mathrm{Cm} 2)$ or $28 \mathrm{KN} / \mathrm{m} 2$. Theshear strength of that composed of $4 \%$ bentonite and $6 \%$ Portland cement was $2.7(\mathrm{~N} / \mathrm{Cm} 2)$ or $27 \mathrm{KN} / \mathrm{m} 2$. The combination of $6 \%$ bentonite and $4 \%$ Portland cementgenerated a sand mould with a shear strength of $2.63(\mathrm{~N} / \mathrm{Cm} 2)$ or $26.3 \mathrm{KN} / \mathrm{m} 2$. The shear strength of the specimen contained a mixture of $7 \%$ bentonite and $3 \%$ Portland cement was $2.86(\mathrm{~N} / \mathrm{Cm} 2)$ or $28.6 \mathrm{KN} / \mathrm{m} 2$. In sum, the shear strength of the four specimens has fulfilled the standard of shear strength of a sand mould, i.e. 1.5-7 Psi or 1.04$4.83 \mathrm{~N} / \mathrm{cm} 2[10]$.

\section{Tensile Testing on the Moulding Sand}

The tension testing was performed to determine the maximum tensile strength of the moulding sand per unit area until broken. Low tensile strength will cause mould shrinkagedue to the volume contraction of the molten metal. According to [11], the standard tensile strength of amoulding sand is 1-6 Psi. The tensile testing on the specimen composed of 5\% bentonite and 5\% Portland cement showed that it had a tensile strength of $0.51\left(\mathrm{~N} / \mathrm{cm}^{2}\right)$ or $5.1 \mathrm{kN} / \mathrm{m} 2$. The tensile strength of the mould composed of $4 \%$ bentonite and $6 \%$ Portland cement was $0.51(\mathrm{~N} / \mathrm{Cm} 2)$ or $5.1 \mathrm{kN} / \mathrm{m} 2$. The specimen composed of $6 \%$ bentonite and $4 \%$ Portland cement had a tensile strength of $0.51\left(\mathrm{~N} / \mathrm{cm}^{2}\right)$ or 5.1 $\mathrm{kN} / \mathrm{m}^{2}$. The combination of $7 \%$ bentonite and $3 \%$ Portland cement generated a mould with a tensile 
strength of $0.46\left(\mathrm{~N} / \mathrm{cm}^{2}\right)$ or $4.6 \mathrm{kN} / \mathrm{m}^{2}$. As already stated by Heine (1976:95), moulding sand should have a tensile strength of 1-6 Psi or $0,69-4,14 \mathrm{~N} / \mathrm{cm}^{2}$.

The strength testing (compressive, shear, tensile) was followed up with the SEM testing. The results of SEM analysis on four moulds made of mixtures with different concentrations of sand, bentonite and Portland cement are presented in Figure 1.

\section{Permeability Testing}

Permeability testing was carried out to determine the ability of the moulding sand to transmit fluid or gasesthrough unit area of specimen per unit time $\left(\mathrm{ml} / \mathrm{cm}^{2}\right)$.

The low permeability of moulding sand causes difficulty for air to pass through the grains. As a result, when molten metal is poured, gases/air cannot escape and hence defect in the casting.In contrary, gases can come out much more easily in a mould with high permeability [12]. However, if the permeability is too high, the molten metal poured can seep in between the sand grains and result in a rough surface on the casting [12].

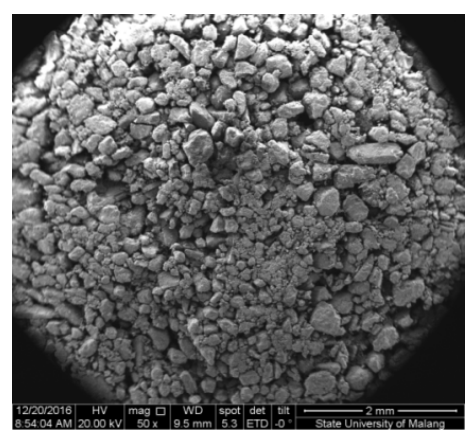

Figure 1.Moulding Sand 5\% B + 5\% PC

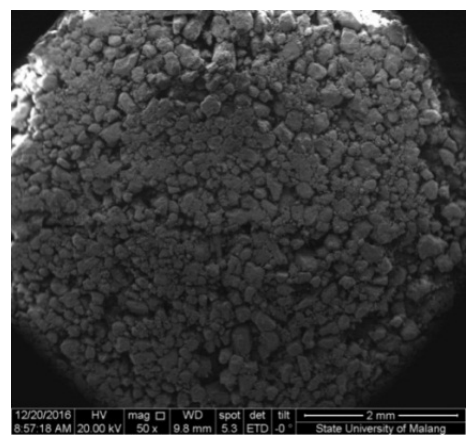

Figure 3. Moulding Sand 6\% B $+4 \%$ PC

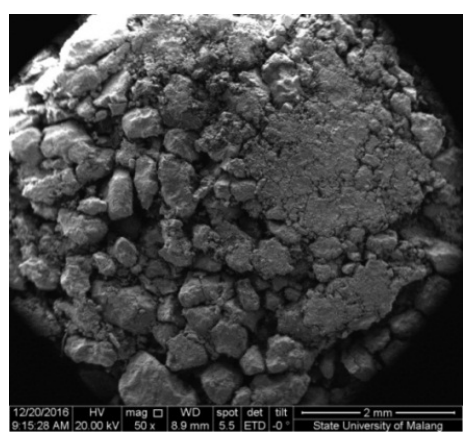

Figure 2.Moulding Sand 4\% B + 6\% PC

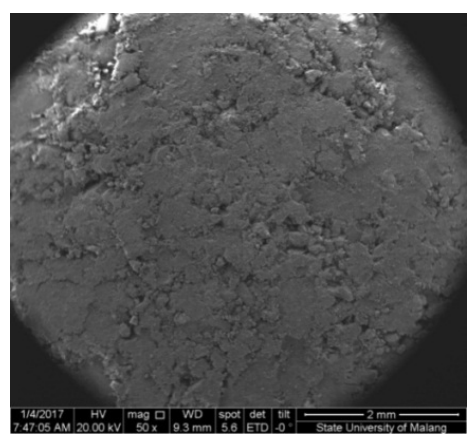

Figure 4. Moulding Sand 7\% B + 3\% PC

Table 2. The Permeability of moulding sand

\begin{tabular}{cl}
\hline Specimen & Permeability \\
\hline $6 \% \mathrm{~B}+4 \%$ PC & $176 \mathrm{ml} /$ minute \\
\hline $5 \% \mathrm{~B}+5 \% \mathrm{PC}$ & $131 \mathrm{ml} / \mathrm{minute}$ \\
\hline $4 \% \mathrm{~B}+6 \% \mathrm{PC}$ & $131 \mathrm{ml} /$ minute \\
\hline $7 \% \mathrm{~B}+3 \% \mathrm{PC}$ & $151 \mathrm{ml} /$ minute \\
\hline
\end{tabular}




\section{Conclusions.}

Taken together, the findings and discussion of this research suggest the following conclusions.

1. Among the other three specimens, the moulding sand combined with $6 \% \mathrm{~B}+4 \% \mathrm{PC}$ had the highest compressive strength $(8.13 \mathrm{~N} / \mathrm{mm} 2)$, whilethat with $5 \% \mathrm{~B}+5 \%$ PChad the lowest compressive strength $(7.2 \mathrm{~N} / \mathrm{mm} 2)$

2. The highest shear strength was obtained from the moulding sand mixed with $7 \% \mathrm{~B}+3 \% \mathrm{PC}$ $(2.86 \mathrm{~N} / \mathrm{mm} 2)$, while the lowest shear strength was obtained fromthat with $6 \% \mathrm{~B}+$ $4 \% \mathrm{PC}(2.6 \mathrm{~N} / \mathrm{mm} 2)$.

3. The highest shear strength of $0.51 \mathrm{~N} / \mathrm{mm} 2$ was obtained from three variations of sand mixture, i.e. $5 \% \mathrm{~B}+5 \% \mathrm{PC}, 4 \% \mathrm{~B}+6 \% \mathrm{PC}$, and $6 \% \mathrm{~B}+4 \% \mathrm{PC}$, while the lowest shear strength was obtained from that with $7 \% \mathrm{~B}+3 \% \mathrm{PC}$ had the lowest compressive strength $(0.46 \mathrm{~N} / \mathrm{mm} 2)$

4. Based on the results of the compression, shear, and tensile testing, all specimens are considered to have satisfied the criteria for ideal moulding sand.

\section{References}

[1] A. I Made, "Pengaruh Jenis Pasir Cetak dengan Zat Pengikat Bentonit terhadap Sifat Permeabilitas dan kekuatan Tekan Basah Cetakan Pasir(Sand Casting)," J. Ilm. Tek.Mesin, vol. 4, no. 2, pp. 132-138, 2010.

[2] J.Choma, L. Osuchowski, M. Marszewski, A. Dziura, and M. Jaroniec, "Developing microporosity in Kevlar®-derived carbon fibers by $\mathrm{CO} 2$ activation for $\mathrm{CO} 2$ adsorption," J. CO2 Util., vol. 16, pp. 17-22, Dec. 2016.

[3] D.Koch, "Bentonites as a basic material for technical base liners and site encapsulation cut-off walls," Appl. Clay Sci., vol. 21, no. 1-2, pp. 1-11, Apr. 2002.

[4] “27,226 Search Results - ALL(BENTONITE) - ScienceDirect.” [Online]. Available: http://www.sciencedirect.com/science?_ob=ArticleListURL\&_method=list\&_ArticleListID1215843383 \&_sort=r\&_st=13\&view =c\&md5=3ef21220f0538507c2b7cd83d73eb8a2\&searchtype=a. [Accessed: 08Jun-2017].

[5] "Modelling and optimization of the sound absorption of wood-wool cement boards ScienceDirect."[Online].Available:http://www.sciencedirect.com/science/article/pii/S0003682X1730433 4. [Accessed: 06-Sep-2017].

[6] C. Lee, S. Park, D. Lee, I.-M. Lee, and H. Choi, "Viscosity and salinity effect on thermal performance of bentonite-based grouts for ground heat exchanger," Appl. Clay Sci., vol. 101, pp. 455460, Nov. 2014.

[7] Y. C. Flores, G. C. Cordeiro, R. D. Toledo Filho, and L. M. Tavares, "Performance of Portland cement pastes containing nano-silica and different types of silica," Constr. Build. Mater., vol.146, pp. 524-530, Aug. 2017.

[8] T. Thyagaraj and D. Soujanya, "Polypropylene fiber reinforced bentonite for waste containment barriers," Appl. Clay Sci., vol. 142, pp. 153-162, Jun. 2017.

[9] A. Yustres et al., "Comparison of the hydrogeochemical and mechanical behaviours of compacted bentonite using different conceptual approaches," Appl. Clay Sci., vol. 141, pp. 280-291, Jun. 2017.

[10] G. Barast, A.-R.Razakamanantsoa, I. Djeran-Maigre, T. Nicholson, and D. Williams, "Swelling properties of natural and modified bentonites by rheological description," Appl. Clay Sci., vol. 142, pp. 60-68, Jun. 2017.

[11]S. Zhao, X. Ding, M. Zhao, C. Li, and S. Pei, "Experimental study on tensile strength development of concrete with manufactured sand," Constr. Build. Mater., vol. 138, pp. 247-253, May 2017.

[12] M. Nojoomizadeh and A. Karimipour, "The effects of porosity and permeability on fluid flow and heat transfer of multi walled carbon nano-tubes suspended in oil (MWCNT/Oil nano-fluid) in a microchannel filled with a porous medium,” Phys. E Low-Dimens. Syst. Nanostructures, vol. 84, pp. 423-433, Oct. 2016. 